\title{
Phaeobotryon negundinis sp. nov. (Botryosphaeriales) from Russia
}

\author{
Daranagama $\mathrm{DA}^{1,2}$, Thambugala $\mathrm{KM}^{2,3}$, Campino $\mathrm{B}^{4}$, Alves $\mathrm{A}^{4}$, Bulgakov $\mathrm{TS}^{5}$, \\ Phillips AJL ${ }^{6}$, Liu X' ${ }^{1}$, Hyde KD ${ }^{2}$
}

1. State Key Laboratory of Mycology, Institute of Microbiology, Chinese Academy of Sciences, No 3 1st West Beichen Road, Chaoyang District, Beijing, 100101, People's Republic of China.

2. Center of Excellence in Fungal Research, Mae Fah Luang University, Chiang Rai, 57100, Thailand

3. Guizhou Key Laboratory of Agricultural Biotechnology, Guizhou Academy of Agricultural Sciences, Guiyang 550006, Guizhou, People's Republic of China

4. Departamento de Biologia, CESAM, Universidade de Aveiro, Campus Universitário de Santiago, 3810-193 Aveiro, Portugal.

5. Academy of Biology and Biotechnology, Southern Federal University, Rostov-on-Don 344090, Rostov region, Russia 6. University of Lisbon, Faculty of Sciences, Biosystems and Integrative Sciences Institute (BioISI), Campo Grande, 1749-016 Lisbon, Portugal

Daranagama DA, Thambugala KM, Campino B, Alves A, Bulgakov TS, Phillips AJL, Liu XZ, Hyde KD 2016 - Phaeobotryon negundinis sp. nov. (Botryosphaeriales) from Russia. Mycosphere 7(7), 933-941, Doi 10.5943/mycosphere/si/1b/2

\begin{abstract}
A new species of Phaeobotryon was collected from Acer negundo, Forsythia $\times$ intermedia and Ligustrum vulgare from European Russia. Morphological and phylogenetic analyses of combined ITS, $\beta$-tubulin and EF1- $\alpha$ sequence data revealed that these collections differ from all other species in the genus. Therefore it is introduced here as Phaeobotryon negundinis sp. nov. It is characterized by immersed-erumpent, uniloculate conidiomata, bearing brown, ovoid, aseptate conidia, with broadly rounded apices and truncate bases. Conidia form a single septum at germination. Phaeobotryon negundinis is morphologically similar to P. cupressi, but has smaller conidia. This is the first time a Phaeobotryon species is reported on Acer negundo, Ligustrum vulgare and Forsythia $\times$ intermedia.
\end{abstract}

Key words - Botryosphaeriaceae - Dothideomycetes - morphology - phylogeny - taxonomy

\section{Introduction}

The family Botryosphaeriaceae is considered to be one of the largest families in the class Dothideomycetes and members of this family comprise a wide range of morphologically diverse taxa that are characterized by uni- to multi-loculate ascostromata, usually 8-spored, bitunicate asci and hyaline to brown, aseptate to 2-septate ascospores (Liu et al. 2012, Phillips et al. 2013). The asexual morphs produce uni to multi-locular pycnidial conidiomata, with hyaline phialidic conidiogenous cells and hyaline or pigmented, septate or aseptate conidia (Phillips et al. 2008, Liu et al. 2012, Hyde et al. 2013, Phillips et al. 2013, Machado et al. 2014, Thambugala et al. 2014, Doilom et al. 2015).

Phaeobotryon was established by Theissen \& Sydow (1915) as a monotypic genus typified by P. cercidis (Cooke) Theiss. \& Syd. In their broad view of Botryosphaeria based on morphology of the sexual morph, von Arx \& Müller $(1954,1975)$ considered Phaeobotryon to be a synonym of 
Botryosphaeria. However, recent studies showed that Phaeobotryon is morphologically and phylogenetically distinct from all other genera in Botryosphaeriaceae (Phillips et al. 2008, Liu et al. 2012, Hyde et al. 2013, Phillips et al. 2013). The genus is characterized by immersed to erumpent, multi-locular ascostromata, clavate to cylindrical-clavate asci and short-pedicellate, hyaline or brown, 2-septate ascospores and ellipsoidal to oblong or obovoid, hyaline or brown conidia, that are mostly 2-septate at maturity (Liu et al. 2012, Hyde et al. 2013, Phillips et al. 2013, Fan et al. 2014). Eight epithets are currently listed in Index Fungorum (2016).

In this paper we introduce Phaeobotryon negundinis as a new species from Acer negundo, Forsythia $\mathrm{x}$ intermedia and Ligustrum vulgare collected from Russia. The species was compared morphologically with other known Phaeobotryon species and its phylogenetic position was determined from an analysis of ITS, $\beta$-tubulin and EF1- $\alpha$ sequence data.

\section{Materials and Methods}

\section{Sampling and morphology}

Fresh specimens were obtained from Acer negundo L., Forsythia $\times$ intermedia Zabel and Ligustrum vulgare L. collected in Russia. Morphological examination and photomicrography were carried out as described by Thambugala et al. (2015) and Daranagama et al. (2015). Axenic cultures were prepared according to the method of Chomnunti et al. (2014) and maintained on potatodextrose agar (PDA; Difco Laboratories). Herbarium material was deposited in the herbarium of Mae Fah Luang University, Chiang Rai, Thailand (MFLU) and cultures deposited at Mae Fah Luang University Culture Collection (MFLUCC). Faces of fungi numbers and Index Fungorum numbers were registered as explained in Jayasiri et al. (2015) and Index Fungorum (2016).

\section{DNA extraction, PCR amplification and sequencing}

DNA was extracted following the method of Thambugala et al. (2015). PCR amplifications

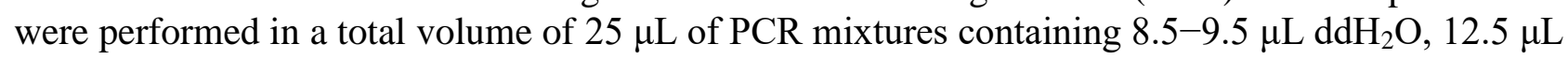
$2 \times$ PCR Master Mix (TIANGEN Co., China), $1-2 \mu \mathrm{L}$ of DNA template, $1 \mu \mathrm{L}$ of each primer. The EF1- $\alpha$ (EF1-728F and EF1-986R), ITS (ITS5/ITS4), LSU (LR0R/LR5) and $\beta$-tubulin (Bt2a and $\mathrm{Bt} 2 \mathrm{~b}$ ) gene regions were amplified following the conditions described in Carbone and Kohn (1999), White et al. (1990), Vilgalys and Hester (1990) and Glass and Donaldson (1995). PCR products were visualized under UV light on $1 \%$ agarose gels stained with ethidium bromide. PCR products were purified and sequenced by Invitrogen Biotechnology Co., Ltd. Shanghai, China.

\section{Phylogenetic analyses}

The phylogenetic position of the new strains was determined in two separate analyses. The first analysis was based on combined EF1- $\alpha$ and ITS sequence data of 56 isolates belonging to Botryosphaeriaceae (Table 1) to show the placement of the genus Phaeobotryon in the family, with Phyllosticta citricarpa as the outgroup taxon. The second analysis, based on combined $\beta$-tubulin, EF1- $\alpha$ and ITS sequence data, was done only for species in Phaeobotryon, which included 14 isolates and Barriopsis fusca as the outgroup taxon. All newly generated sequences were deposited in GenBank (Table 1). Isolates and GenBank accession numbers used in the analyses are listed in Table 1.

The sequence data were combined and aligned with Bioedit v. 7.2.5 (Hall 1999) and MEGA 6.0 (Tamura et al. 2013). Maximum likelihood (ML) analyses were performed using MEGA 6.0. The general time-reversible (GTR) model of evolution including estimation of invariable sites (I) and assuming a discrete gamma distribution $(\mathrm{G})$ was used. All gaps were included in the analyses. ML analyses were performed on a neighbor-joining (NJ) starting tree automatically generated by the software. Nearest-Neighbour-Interchange (NNI) was used as the heuristic method for tree inference and 1000 bootstrap replicates were executed. The best scoring trees were selected for each analysis and figures prepared with Adobe Illustrator CS3. 


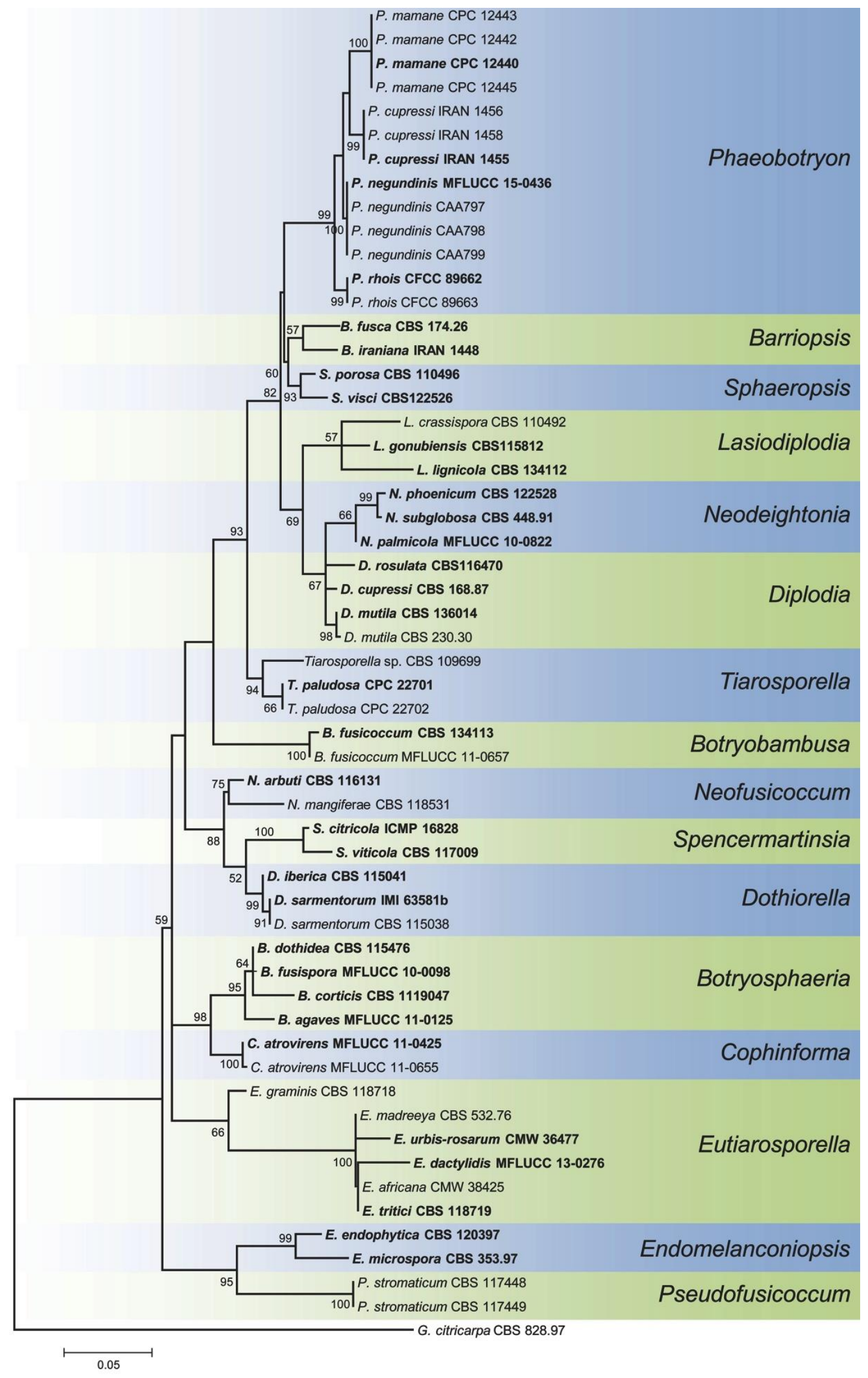

Fig. 1 - Phylogram inferred from maximum likelihood analysis of combined ITS and EF-1 $\alpha$ sequence data. Strain numbers are given after the taxon names. Holo-, neo- or epitype strains/specimens are in bold face. Bootstrap support values $>50 \%$ from 1000 replicates are shown above or below the branches. 


\section{Results}

Phylogenetic analysis

After alignment, the combined ITS and EF-1 $\alpha$ dataset of 55 ingroup taxa had a length of 1060 characters including gaps. Phylogenetic analysis by maximum likelihood resulted in 15 clades corresponding to 15 genera of Botryosphaeriaceae (Fig. 1). The Russian isolates clustered in a wellsupported clade within Phaeobotryon distinct from P. rhois C.M. Tian et al., P. cupressi Abdollahz. et al. and P. mamane Crous \& A.J.L. Phillips. These are the only species for which cultures and sequence data are available. Analysis of the combined ITS, $\beta$-tubulin and EF1- $\alpha$ dataset for Phaeobotryon resulted in four clades corresponding to four species (Fig. 2). Three of the species are already known, while the Russian isolates formed the fourth clade representing a distinct species that we introduce here as $P$. negundinis.

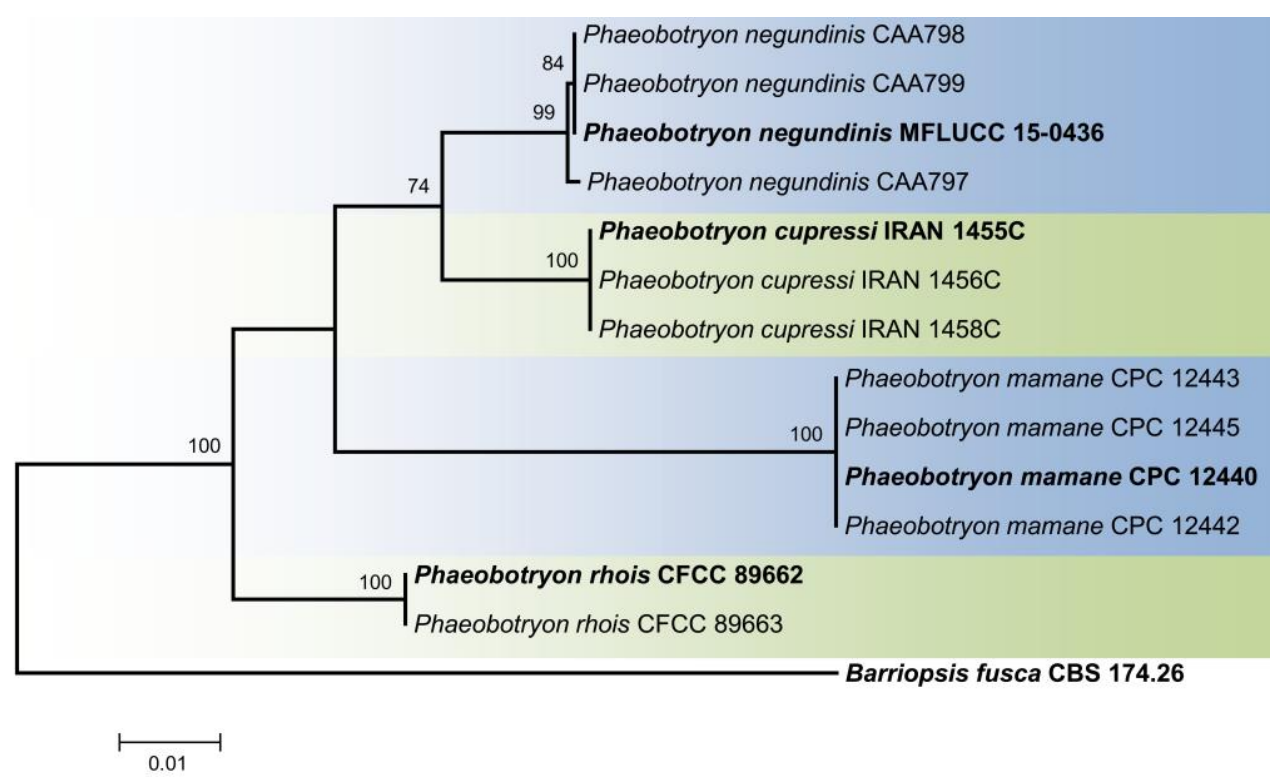

Fig. 2 - Phylogram inferred from maximum likelihood analysis of combined ITS, EF-1 $\alpha$ and $\beta$ tubulin sequence data. The values above/below the branches indicate ML bootstrap support values. Ex-type strains are in boldface.

\section{Taxonomy}

Phaeobotryon negundinis Daranagama, Bulgakov and K.D. Hyde, sp. nov. Facesoffungi number: FoF 01916 Index Fungorum number: IF551954

Etymology - "negundinis" refers to the epithet of the host plant Acer negundo from which it was first isolated

\section{Holotype - MFLU 16-0475}

Necrotrophic on dying and recently dead twigs and branches of Acer negundo. Sexual morph: Not observed. Asexual morph: Conidiomata 200-350 $\mu \mathrm{m}$ high $\times 210-325 \mu \mathrm{m}$ diam. $(\bar{x}=$ $268 \times 253 \mu m, n=6$ ), stromatic, solitary and scattered in small groups, immersed, becoming erumpent through the host tissue, uniloculate, black, globose to subglobose, ostiolate. Conidiomatal wall 30-60 $\mu m(\bar{x}=38.5 \mu m, \mathrm{n}=15)$, comprising several layers of lightly pigmented to dark brown cells of textura angularis becoming hyaline towards the towards the conidiogenous region. Conidiophores reduced to conidiogenous cells. Conidiogenous cells 10-28 $\times(1.8-) 2-4 \mu \mathrm{m}(\bar{x}=$ $16.7 \times 2.8 \mu \mathrm{m}, n=15)$, lining the conidiomatal cavity, holoblastic, hyaline, subcylindrical. Conidia $16-24.5 \times 7.9-11.5 \mu m(\bar{x}=20.1 \times 9.5 \mu m, n=30)$, ovoid with a broadly rounded apex and truncate base, initially hyaline to lightly pigmented, becoming dark brown at maturity, aseptate, forming a single septum at germination, smooth to finely verruculose. 
Table 1 GenBank accession numbers of the strains used in this study.

\begin{tabular}{|c|c|c|c|c|}
\hline \multirow[t]{2}{*}{ Taxon } & \multirow{2}{*}{$\begin{array}{c}\text { Culture Accession } \\
\text { No. }\end{array}$} & \multicolumn{3}{|c|}{ GenBank Accession No. } \\
\hline & & $\beta$-tubulin & ITS & EF1- $\alpha$ \\
\hline Barriopsis fusca & CBS 174.26 & EU673109 & EU673330 & EU673296 \\
\hline Barriopsis iraniana & IRAN 1448 & - & FJ919663 & FJ919652 \\
\hline Botryobambusa fusicoccum & MFLUCC 11-0657 & - & JX646793 & JX646858 \\
\hline Botryobambusa fusicoccum & CBS 134113 & - & JX646792 & JX646857 \\
\hline Botryosphaeria agaves & MFLUCC 11-0125 & - & NR111792 & JX646856 \\
\hline Botryosphaeria corticis & CBS 119047 & - & DQ299245 & EU017539 \\
\hline Botryosphaeria dothidea & CBS 115476 & - & AY236949 & AY236898 \\
\hline Botryosphaeria fusispora & MFLUCC 10-0098 & - & JX646789 & JX646854 \\
\hline Diplodia cupressi & CBS 168.87 & - & DQ458893 & DQ458878 \\
\hline Diplodia mutila & CBS 136014 & - & KJ361837 & KJ361829 \\
\hline Diplodia mutila & CBS 230.30 & - & DQ458886 & DQ458869 \\
\hline Diplodia rosulata & CBS 116470 & - & EU430265 & EU430267 \\
\hline Dothiorella iberica & CBS 115041 & - & AY573202 & AY573222 \\
\hline Dothiorella sarmentorum & IMI $63581 \mathrm{~b}$ & - & AY573212 & AY573235 \\
\hline Dothiorella sarmentorum & CBS 115038 & - & AY573206 & AY573223 \\
\hline Endomelanconiopsis endophytica & CBS 120397 & - & EU683656 & EU683637 \\
\hline Endomelanconiopsis microspora & CBS 353.97 & - & EU683655 & EU683636 \\
\hline Eutiarosporella africana & CMW38423 & - & KC769956 & KC769852 \\
\hline Eutiarosporella africana & CMW38425 & - & KC769958 & KC769854 \\
\hline Eutiarosporella dactylidis & MFLUCC 13-0276 & - & KM978944 & KP031694 \\
\hline Eutiarosporella madreeya & CBS 532.76 & - & КC769960 & \\
\hline Eutiarosporella tritici & CBS 118719 & - & KF531830 & KF531809 \\
\hline Eutiarosporella urbis-rosarum & CBS 130405 & - & JQ239407 & JQ239394 \\
\hline Phyllosticta citricarpa & CBS 828.97 & - & FJ538318 & FJ538376 \\
\hline Lasiodiplodia crassispora & CBS 110492 & - & EF622086 & EF622066 \\
\hline Lasiodiplodia gonubiensis & CBS 115812 & - & AY639595 & DQ103566 \\
\hline Lasiodiplodia lignicola & CBS 134112 & - & JX646797 & JX646862 \\
\hline Marasasiomyces karoo & CBS 118718 & - & KF531828 & KF531807 \\
\hline Neodeightonia palmicola & MFLUCC 10-0822 & - & HQ199221 & 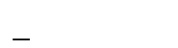 \\
\hline Neodeightonia phoenicum & CBS 122528 & - & EU673340 & $\bar{E}$ EU673309 \\
\hline Neodeightonia subglobosa & CBS 448.91 & - & EU673337 & EU673306 \\
\hline Neofusicoccum arbuti & CBS 116131 & - & AY819720 & KF531792 \\
\hline Neofusicoccum mangiferae & CBS 118531 & - & AY615185 & DQ093221 \\
\hline Phaeobotryon cupressi & IRAN 1455 & - & FJ919672 & FJ919661 \\
\hline Phaeobotryon cupressi & IRAN 1456 & - & FJ919670 & FJ919659 \\
\hline Phaeobotryon cupressi & IRAN 1458 & - & FJ919671 & FJ919660 \\
\hline Phaeobotryon mamane & CPC 12440 & EU67312 & EU673332 & EU673298 \\
\hline Phaeobotryon mamane & CPC 12442 & EU673124 & EU673333 & EU673299 \\
\hline Phaeobotryon mamane & CPC 12443 & EU673120 & EU673334 & EU673300 \\
\hline Phaeobotryon mamane & CPC 12445 & EU673122 & EU673302 & EU673336 \\
\hline Phaeobotryon negundinis & MFLUCC 15-0436 & KU853996 & KU820970 & KU853997 \\
\hline Phaeobotryon negundinis & CAA 797 & KX061510 & KX061513 & KX061507 \\
\hline Phaeobotryon negundinis & CAA 798 & KX061511 & KX061514 & KX061508 \\
\hline Phaeobotryon negundinis & CAA 799 & KX061512 & KX061515 & KX061509 \\
\hline Phaeobotryon rhois & CFCC 89662 & - & KM030584 & KM030598 \\
\hline Phaeobotryon rhois & CFCC 89663 & - & KM030585 & KM030599 \\
\hline Pseudofusicoccum stromaticum & CBS 117448 & - & AY693974 & AY693975 \\
\hline Pseudofusicoccum stromaticum & CBS 117449 & - & DQ436935 & DQ436936 \\
\hline Spencermartinsia citricola & ICMP 16828 & - & EU673323 & EU673290 \\
\hline Spencermartinsia viticola & CBS 117009 & - & AY905554 & AY905559 \\
\hline Sphaeropsis porosa & CBS 110496 & - & AY343379 & AY343340 \\
\hline Sphaeropsis visci & CBS 186.97 & - & EU673325 & EU673293 \\
\hline Tiarosporella paludosa & CPC 22701 & - & KM108378 & - \\
\hline Tiarosporella paludosa & СРC 22702 & - & KM108379 & - \\
\hline Tiarosporella sp. & CBS 109699 & - & KM108380 & KM108429 \\
\hline
\end{tabular}

Abbreviations: CAA: Collection of Artur Alves housed at Department of Biology, University of Aveiro, Portugal; CBS: Centraalbureau voor Schimmelcultures, Utrecht, The Netherlands; CFCC: China Forestry Culture Collection Center; CMW: FABI, University of Pretoria, South Africa; ICMP International Collection of Micro-organisms from 
Plants, Landcare Research, New Zealand; CPC Collection of Pedro Crous housed at CBS; IMI International Mycological Institute, CABI-Bioscience, Egham, Bakeham Lane, U.K; MFLUCC: Mae Fah Luang University Culture Collection, Chiang Rai, Thailand.
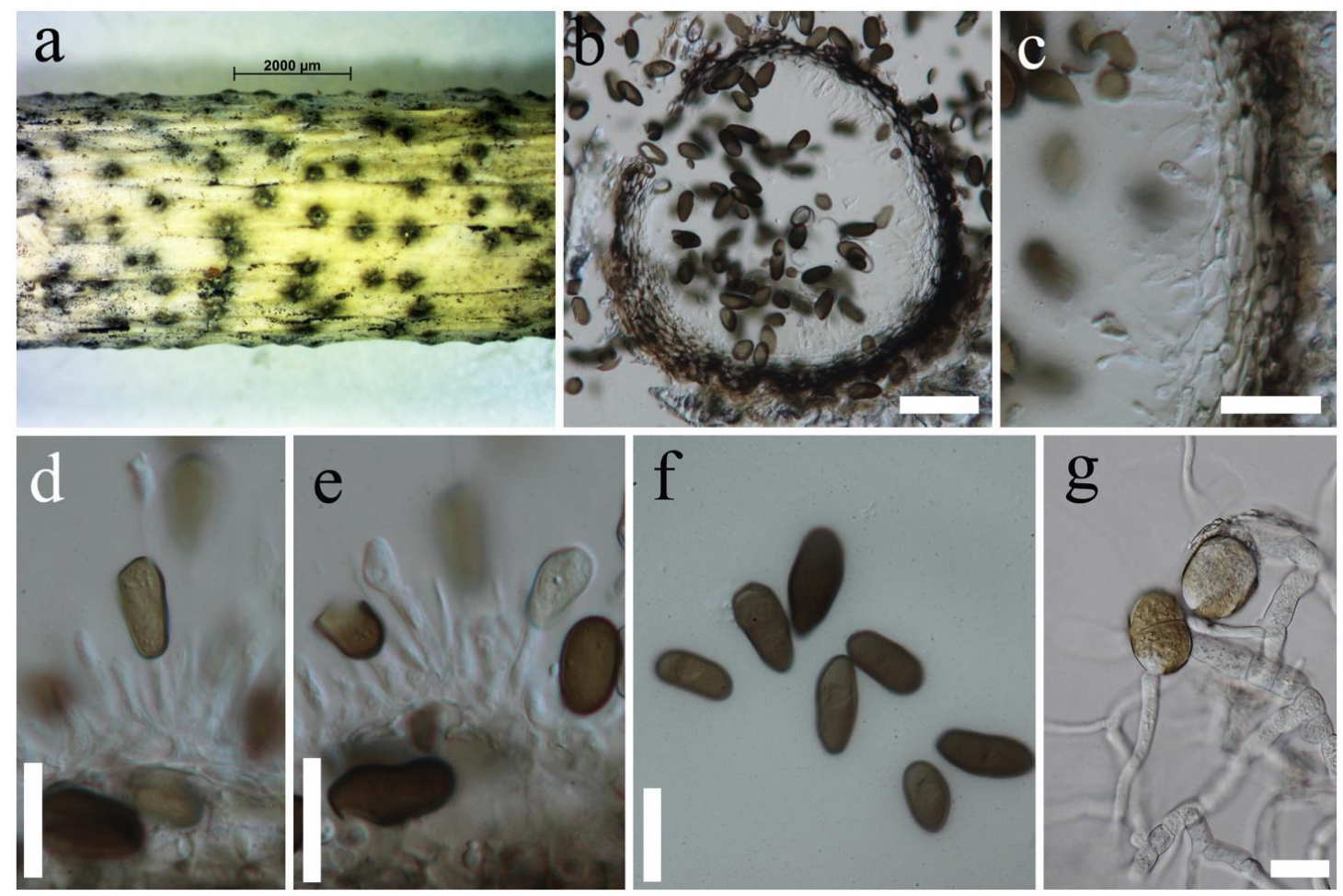

Fig. 3. Phaeobotryon negundinis (MFLU 16-0475, holotype) a. Appearance of conidiomata on host surface. b. Vertical section through conidioma. c. Conidiomatal wall. d, e. Conidia developing on conidiogenous cells f. Conidia. g. Germinating conidia. Scale bars: $\mathrm{a}, \mathrm{b}=50 \mu \mathrm{m}, \mathrm{c}, \mathrm{g}=25 \mu \mathrm{m}$, $\mathrm{d}-\mathrm{f}=20 \mu \mathrm{m}$.
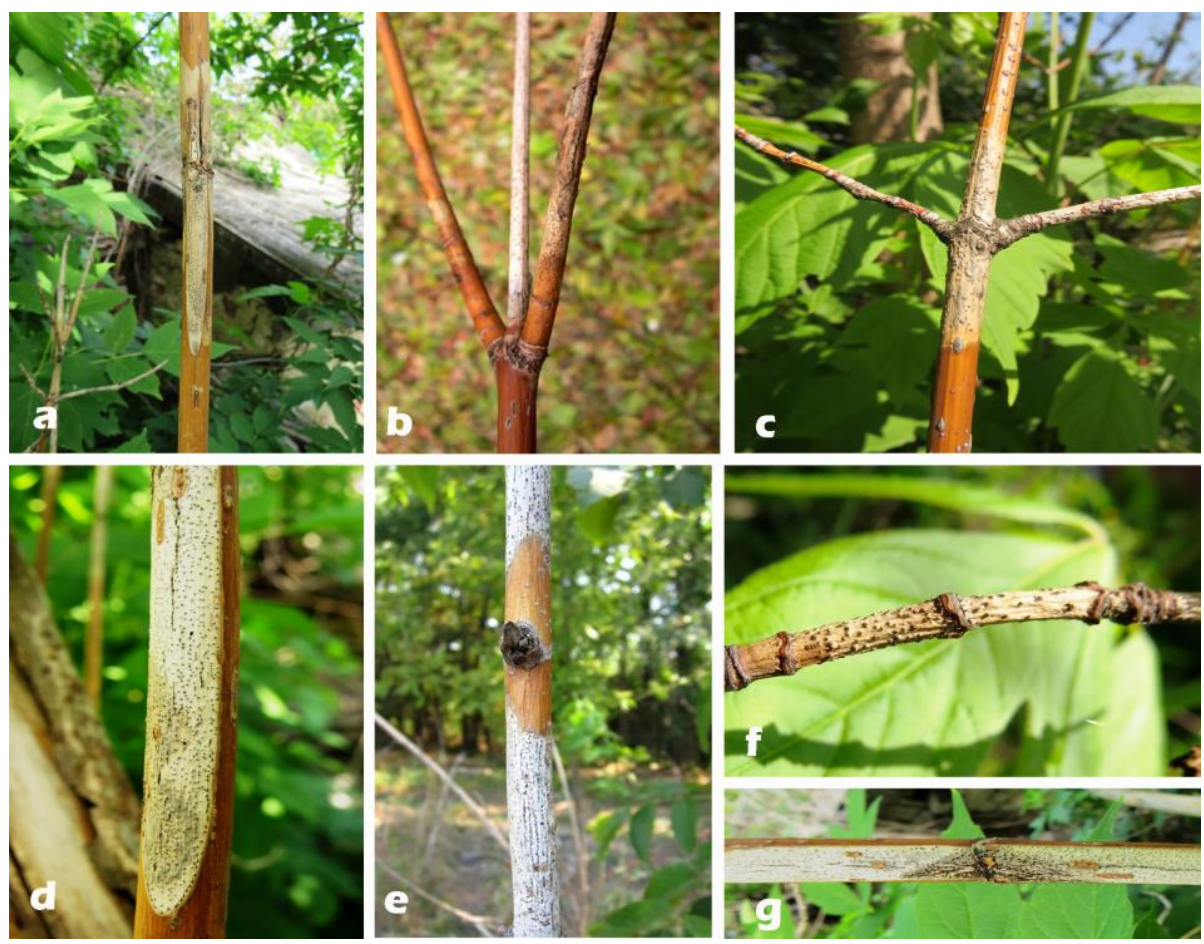

Fig. 4 - Phaeobotryon negundinis on Acer negundo. Dark pycnidia - a-c. On twigs, d-g. On branches. 
Cultural characteristics - Conidia germinating on PDA within $18 \mathrm{~h}$. Colonies fast growing on PDA at $25{ }^{\circ} \mathrm{C}$, covering the medium surface $(9 \mathrm{~cm}$ Petri-dishes) after 7 days, circular, flat, dense, surface initially white, becoming gray from the centre within 7 days, smooth surface with entire to slightly undulate edge.

Material examined - Russia, Rostov region, Rostov-on-Don city, Botanical Garden of Southern Federal University, Higher Park, on dying and dead twigs and branches of Acer negundo L. (Sapindaceae), 05 March 2014, T.S. Bulgakov (MFLU 16-0475, holotype), ibid. GZAAS 150103 isotype; ex-type living culture MFLUCC 15-0436, ICMP. GB Accession numbers: KU853996 ( $\beta$-tubulin), KU853997 (EF-1 $\alpha$ ), KU820970 (ITS), KU820971 (LSU); Shakhty city, Central Park, on dying and dead twigs and branches of Acer negundo L. (Sapindaceae), 12 March 2014, T.S. Bulgakov, living culture CAA 797; on twigs and branches of Ligustrum vulgare L. (Oleaceae), 12 March 2014, T.S. Bulgakov, living culture CAA 798; Krasnosulinsky district, Donskoye forestry, forest nursery, on twigs and branches of Forsythia $\times$ intermedia Zabel (Oleaceae), 21 May 2014, T.S. Bulgakov, living culture CAA 799.

Notes - Phylogenetically Phaeobotryon negundinis is most closely related to P. cupressi. The two species can be differentiated morphologically on account of the smaller conidia of $P$. negundinis.

\section{Discussion}

In this paper Phaeobotryon negundinis is introduced as a new species that is phylogenetically distinct from all other species in the genus. The smaller conidia of P. negundinis differentiate it from its nearest relative ( $P$. cupressi). The 2-septate, brown ascospores with an apiculus at either end differentiate Phaeobotryon from all other genera in Botryosphaeriaceae. The sexual morph of $P$. negundinis was not seen on the host and did not form in culture.

Eight epithets are listed in Index of Fungi under Phaeobotryon, but only four species are known in culture and with DNA sequence data in GenBank. Unfortunately no DNA sequence data are available for the generic type of Phaeobotryon, and no cultures are extant. Therefore all the known species need to be recollected and sequenced to establish a complete phylogeny of the genus.

Although $P$. negundinis was associated with disease symptoms on twigs, leaves and seeds, pathogenicity has not been proved. Considering the number of different fungi that are associated with the same symptoms (Bulgakov, unpublished data) it is not possible to determine if $P$. negundinis is a primary pathogen or a secondary invader of already diseased tissues. Furthermore, there is no information available on the pathogenic status of any of the species in Phaeobotryon. This is the first report of a Phaeobotryon species on Acer negundo, Forsythia $\times$ intermedia and Ligustrum vulgare. Considering that Phaeobotryon is a relatively small genus with nine species, only five of which are known in culture, it can be expected that further sampling will reveal more species.

\section{Acknowledgments}

The authors appreciate the financial support and postgraduate scholarship provided by the State Key Laboratory of Mycology, Institute of Microbiology, Chinese Academy of Sciences, Beijing and the Mushroom Research Foundation, Chiang Mai, Thailand. Artur Alves acknowledges financing by European Funds through COMPETE and by National Funds through the Portuguese Foundation for Science and Technology (FCT) to the research unit CESAM (UID/AMB/50017/2013 - POCI-01-0145-FEDER-007638) and himself (FCT Investigator Programme - IF/00835/2013). The authors gratefully thank Dr. Shaun Pennycook from Landcare Research, Auckland, New Zealand for nomenclature advice on the proposed name.

\section{References}

Arx JA von, Müller E. 1954 - Die Gattungen der amerosporen Pyrenomyceten. Beiträge zur Kryptogamenflora der Schweiz 11(1), 1-434. 
Arx JA von, Müller E. 1975 - A re-evaluation of the bitunicate ascomycetes with keys to families and genera. Studies in Mycology 9, 1-15.

Carbone I, Kohn LM. 1999 - A method for designing primer sets for speciation studies in filamentous ascomycetes. Mycologia. 1, 553-556.

Chomnunti P, Hongsanan S, Aguirre-Hudson B, Tian Q, Peršoh D, Dhami MK, Alias AS, Xu J, Liu X, Stadler M, Hyde KD. 2014 - The Sooty Moulds. Fungal Diversity 66, 1-36.

Daranagama DA, Camporesi E, Tian Q, Liu X, Chamyuang S, Stadler M, Hyde KD. 2015 Anthostomella is polyphyletic comprising several genera in Xylariaceae. Fungal Diversity 73, 203-238

Doilom M, Shuttleworth LA, Roux J, Chukeatirote E, Hyde KD. 2015 - Botryosphaeriaceae associated with Tectona grandis (teak) in Northern Thailand. Phytotaxa 233, 1-26.

Fan XL, Hyde KD, Liu JK, Liang YM, Tian CM. 2014 - Multigene phylogeny and morphology reveal Phaeobotryon rhois sp. nov. (Botryosphaeriales, Ascomycota). Phytotaxa 205, 9098.

Glass NL, Donaldson GC. 1995 - Development of primer sets designed for use with the PCR to amplify conserved genes from filamentous ascomycetes. Applied and Environmental Microbiology 1;61(4), 1323-1330.

Hall TA (1999) BioEdit: a user-friendly biological sequence alignment editor and analysis program for Windows 95/98/NT. Nucleic Acids Symposium Series 41, 95-98

Hyde KD, Jones EBG, Liu JK, Ariyawansa HA, Boehm E, Boonmee S, Braun U, Chomnunti P, Crous PW, Dai DQ, Diederich P, Dissanayake A, Doilom M, Doveri F, Hongsanan S, Jayawardena R, Lawrey JD, Li YM, Liu YX, Lücking R, Monkai J, Muggia L, Nelsen MP, Pang KL, Phookamsak R, Senanayake I, Shearer CA, Suetrong S, Tanaka K, Thambugala KM, Wijayawardene NN, Wikee S, Wu HX, Zhang Y, Aguirre-Hudson B, Alias SA, Aptroot A, Bahkali AH, Bezerra JL, Bhat DJ, Camporesi E, Chukeatirote E, Gueidan C, Hawksworth DL, Hirayama K, Hoog SD, Kang JC, Knudsen K, Li WJ, Li XH, Liu ZY, Mapook A, McKenzie EHC, Miller AN, Mortimer PE, Phillips AJL, Raja HA, Scheuer C, Schumm F, Taylor JE, Tian Q, Tibpromma S, Wanasinghe DN, Wang Y, Xu JC, Yan JY, Yacharoen S, Zhang M. 2013 - Families of Dothideomycetes. Fungal Diversity 63, 1-313.

Index Fungorum (2016) http://www.indexfungorum.org/Names/Names. asp, Accession Date -02 February 2016

Jayasiri SC, Hyde KD, Ariyawansa HA, Bhat J, Buyck B, Cai L, Dai YC, Abd-Elsalam KA, Ertz D, Hidayat I, Jeewon R, Jones EBG, Bahkali AH, Karunarathna SC, Liu JK, Luangsa-ard JJ, Lumbsch HT, Maharachchikumbura SSN, McKenzie EHC, Moncalvo JM, GhobadNejhad M, Nilsson H, Pang KA, Pereira OL, Phillips AJL, Raspé O, Rollins AW, Romero AI, Etayo J, Selçuk F, Stephenson SL, Suetrong S, Taylor JE, Tsui CKM, Vizzini A, AbdelWahab MA, Wen TC, Boonmee S, Dai DQ, Daranagama DA, Dissanayake AJ, Ekanayaka AH, Fryar SC, Hongsanan S, Jayawardena RS, Li WJ, Perera RH, Phookamsak R, de Silva NI, Thambugala KM, Tian Q, Wijayawardene NN, Zhao RL, Zhao Q, Kang JC, Promputtha I. 2015 - The Faces of Fungi database: fungal names linked with morphology, phylogeny and human impacts. Fungal Diversity 74, 3-18.

Liu JK, Phookamsak R, Doilom M, Wikee S, Li YM, Ariyawansha H, Boonmee S, Chomnunti P, Dai DQ, Bhat JD, Romero AI, Zhuang WY, Monkai J, Jones EBG, Chukeatirote E, Ko-Ko TW, Zhao YC, Wang Y, Hyde KD. 2012 - Towards a natural classification of Botryosphaeriales. Fungal Diversity 57, 149-210.

Machado AR, Pinho DB, Pereira OL. 2014 - Phylogeny, identification and pathogenicity of the Botryosphaeriaceae associated with collar and root rot of the biofuel plant Jatropha curcas in Brazil, with a description of new species of Lasiodiplodia. Fungal Diversity 67, 231-247.

Phillips AJL, Alves A, Pennycook SR, Johnston PR, Ramaley A, Akulov A, Crous PW. 2008 Resolving the phylogenetic and taxonomic status of dark-spored teleomorph genera in the Botryosphaeriaceae. Persoonia 21, 29-55. 
Phillips AJL, Alves A, Abdollahzadeh J, Slippers B, Wingfield MJ, Groenewald JZ, Crous PW. 2013 - The Botryosphaeriaceae: genera and species known from culture. Studies in Mycology 76, 51-167.

Tamura, K., Stecher, G., Peterson, D., Filipski, A., \& Kumar S. (2013). MEGA6: Molecular Evolutionary Genetics Analysis version 6.0. Molecular Biology and Evolution 30, 27252729.

Thambugala KM, Daranagama DA, Camporesi E, Singtripop C, Liu ZY, Hyde KD. 2014 -Multilocus phylogeny reveals the sexual state of Tiarosporella in Botryosphaeriaceae. Cryptogamie Mycologie 35, 359-367.

Thambugala KM, Hyde KD, Tanaka K, Tian Q, Wanasinghe DN, Ariyawansa, HA, Jayasiri SC, Boonmee S, Camporesi E, Hashimoto A, Hirayama K, Schumacher RK, Promputtha I, Liu ZY. 2015 - Towards a natural classification and backbone tree for Lophiostomataceae, Floricolaceae, and Amorosiaceae fam.nov. Fungal Diversity 74, 199-266.

Theissen F, Sydow H. 1915 - Die Dothideales. Kritisch-systematische Originaluntersuchungen (Continuatio). Annales Mycologici 13, 431-746.

Vilgalys R, Hester M. 1990 - Rapid genetic identification and mapping of enzymatically amplified ribosomal DNA from several Cryptococcus species. Journal of bacteriology172, 42384246.

White TJ, Bruns TD, Lee S, Taylor JW. 1990 - Amplification and direct sequencing of fungal ribosomal RNA for phylogenetics. In: Innis MA, Gelfand DH, Sninsky JJ,White TJ (eds) PCR protocols: a guide to methods and applications. Academic, San Diego, 315-322 